\title{
Awake Carotid Endarterectomy in Patients Undergoing Cardiac Surgery: Our 6 Years of Experience
}

\author{
Kürşad Öz,, Ünal Aydın Aydın,, Bilge Ecemiş Aydın, ${ }^{1}$ Burak Onan, \\ Zeynep Karaman, ${ }^{2}$ Mehmet Ertürk, ${ }^{3}$ Okan $\mathrm{Akıncl}^{4}$
}

\begin{abstract}
'Department of Cardiovascular Surgery, Istanbul Mehmet Akif Ersoy Thoracic and Cardiovascular Surgery Training and Research Hospital,

2Department of Anaesthesiology, Istanbul Mehmet Akif Ersoy Thoracic and Cardiovascular Surgery Training and Research Hospital, ${ }^{3}$ Department of Cardiology, Istanbul Mehmet Akif Ersoy Thoracic and Cardiovascular Surgery Training and Research Hospital,

${ }^{4}$ Department of Radiology, Istanbul Mehmet Akif Ersoy Thoracic and Cardiovascular Surgery Training and Research Hospital; all İstanbul, Turkey

Submitted: 24.12.2016 Accepted: 28.12.2016

Correspondence: Kürşad Öz Osmaniye Mah., Fildamı Aralığı Sok., Fildamı Sit., A. Blok, D: 40 Bakırköy, Istanbul, Turkey E-mail: drkursadoz@gmail.com

口ista

Keywords: Cardiac surgery; carotid endarterectomy; regional anesthesia.
\end{abstract}

\begin{abstract}
Objective: Optimal surgical approach for patients with hemodynamically significant carotid and cardiac disease remains controversial.

Methods: Total of 370 randomized patients who underwent 412 carotid endarterectomies (42 cases were bilateral) and cardiac surgery between 2009 and 2014 were enrolled in the study. All patient data, including demographic details, risk factors, immediate perioperative events, 30-day and long-term outcome, were prospectively recorded and then analyzed statistically as mean and SD.
\end{abstract}

Results: Of the patients, $29.4 \%(n=108)$ were female and $70.6 \%(n=262)$ were male. Mean age was 64 years (range: $42-86$ years). In all, $37.03 \%(n=137)$ of the patients were defined as symptomatic. Asymptomatic severe carotid artery stenosis $(\geq 70 \%)$ was diagnosed in $62.98 \%(n=233)$ of the patients. Mean observation time in intensive care unit following surgery was $2.84( \pm 1.20)$ hours and total hospital stay was $3.72( \pm 1.64)$ days. Restenosis was diagnosed in 7 (I.69\%) of the patients during follow-up. Rate of cardiac events and stroke in postoperative early term were $2.94 \%$ and $0.72 \%$, respectively.

Conclusion: Awake carotid endarterectomy is safe and reliable procedure. Patient consciousness can be optimally evaluated during operation with regional anesthesia, thereby allowing for precise determination of need for shunt and avoiding unnecessary use.

\section{INTRODUCTION}

Stroke ranks third after heart disease and cancer as leading cause of death. Carotid artery stenosis, the most investigated etiological factor of stroke, is responsible for $30 \%$ to $35 \%$ of all ischemic strokes..$^{[1,2]}$ Other causes include fibromuscular disease, cystic medial necrosis, arteritis, and arterial dissection. Carotid artery stenosis of $70 \%$ of the lumen is considered significant, and increases risk of ipsilateral embolic stroke 2 to 3 times. ${ }^{[2]}$

Most common cause of carotid artery stenosis is atherosclerosis. ${ }^{[3]}$ Carotid endarterectomy is currently standard method of revascularization in treatment of severe carotid artery stenosis. Randomized, controlled, multicenter studies, and meta-analysis have examined results of carotid endarterectomy performed in cases with varying degrees of symptomatic and asymptomatic carotid artery stenosis, and procedure has been shown to reduce incidence of stroke and death. ${ }^{[4-6]}$ There is increased incidence of carotid artery disease and coronary artery disease (CAD) in elderly patients. Priority of pathology and proper timing for surgery in such cases is still subject to debate. ${ }^{[7-12]}$ Coincidental carotid artery disease has been detected in $8 \%$ to $14 \%$ of coronary artery bypass patients. ${ }^{[13]}$ Some $40 \%$ 
to $50 \%$ of patients who undergo carotid endarterectomy have CAD. ${ }^{[14]}$ Perioperative risk of myocardial infarction (MI) has been reported to be $17 \%$ for carotid endarterectomy in patients with untreated CAD and $20 \%$ risk of death. Similarly, untreated carotid artery disease carries risk of stroke after coronary bypass. ${ }^{[15,16]}$

Although neurological functions of the patient can be fully monitored in vigilant carotid endarterectomy, selection of anesthesia for patients undergoing coronary bypass operation and choice of synchronous or phased approach to treatment remain controversial.

In this study, characteristics of patients who underwent carotid endarterectomy with regional anesthesia before cardiac surgery and early and long-term outcomes of these patients were investigated.

\section{MATERIAL AND METHODS}

\section{Patient selection}

Total of 370 patients who underwent 412 carotid endarterectomy procedures with regional anesthesia between 2009 and 2014 were included in the present study. Details of demographic data, preoperative risk factors, perioperative, postoperative complications, early (first 30 days) and late neurological findings were examined for all patients. The ethics committee of Istanbul Mehmet Akif Ersoy Thoracic and Cardiovascular Surgery Education and Research Hospital approved the study, written informed consent was obtained from all the patients, and study was conducted according to the Helsinki Declaration.

Doppler ultrasonography (USG) was performed on all pa- tients and diagnosis was confirmed with digital subtraction angiography, computed tomography (CT) or magnetic resonance (MR) angiography. Patients with symptomatic cerebrovascular disease and moderate or severe carotid stenosis requiring treatment, and cardiac patients with stable angina of New York Heart Association class I or II were enrolled in the study. Cardiac operation was performed I week after carotid endarterectomy procedure unless there was specific condition or complication (Table 3).

\section{Anesthesia technique}

The same surgical team performed all operations. All neurological symptoms were recorded preoperatively and perioperatively. Deep and superficial cervical block anesthesia were administered to all patients. Deep cervical plexus block of C2-3-4 cervical nerve dermatomes was combined with 5 to $10 \mathrm{~mL}$ of $0.25 \%$ bupivacaine and $1 \%$ prilocaine injection followed by superficial cervical plexus block. Superficial cervical plexus block of 15 to $20 \mathrm{~mL}$ of $1 \%$ lidocaine was administered to achieve subcutaneous tissue infiltration in the posterior head region of the sternocleidomastoid muscle. Complete and thorough assessment of all patients included intraoperative hemodynamics, arterial monitoring, evaluation of neurological consciousness and cooperation, and motor function testing using plastic, compression ball in contralateral hand.

\section{Surgical technique}

Patients were awake and cooperative during continuous monitoring of neurological condition. Intravenous $5000 \mathrm{IU}$ heparin was administered to all patients before clamping. Controlled hypertension was maintained by the anesthe-
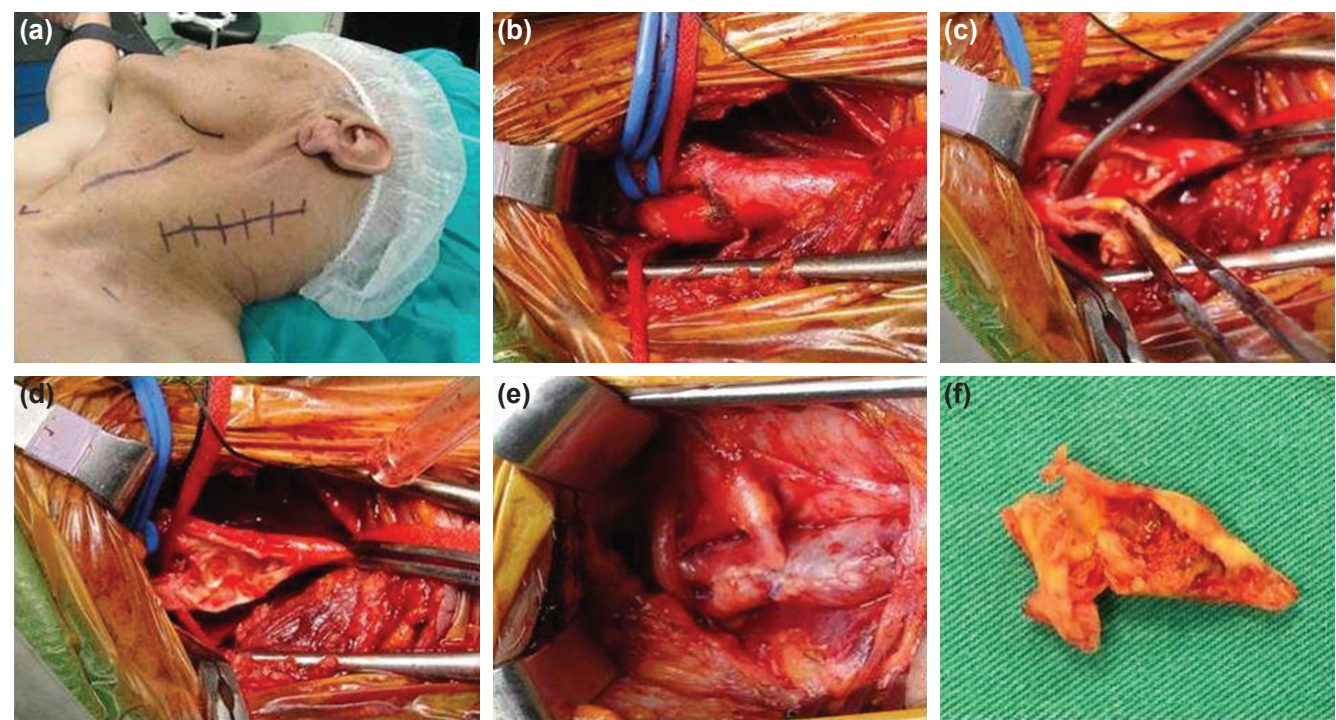

Figure 1. Presentation of carotid endarterectmy with loco-regional anaesthesia. (a) Preparation of patient for regional anaesthesia, (b) exploration of carotid arteries, (c) atheromatous plaque removed after arteriotomy, (d) apperance of inner side of arterial lumen after endarterectomy, (e) direct suturing of arteriotomy, and (f) macroscopic appereance of removed atheromatous plaque. 
tist during carotid clamping. Anesthetist tested state of consciousness with verbal stimuli and confirmed motor functions. Operation was performed if no neurological changes were observed within 5 seconds after carotid clamping. If change in consciousness occurred during clamping, decision was made to use vascular shunt during operation. Standard surgical technique is atherosclerotic plaque removal and carotid artery reconstruction (Figure I). Following the operation, the patient remained in intensive care unit for 2 to 4 hours before transfer to room. Data regarding operative time, cross-clamp time, complications within 30 days associated with operation were recorded. Subsequent checks were made by the neurologist on the 30 th day and every 6 months on follow-up.

\section{Short-term follow up}

Postoperatively, patients were monitored in intensive care unit until hemodynamically stable. Any neurological deficit was checked by a neurologist, and if necessary, cranial CT scan was performed. Patients were assessed with National Institutes of Health Stroke Scale and Rankin Scale. Shortterm neurological deficits were evaluated as transient neurological deficits. Rankin score of 2 or less and few lacunar changes were accepted as good prognostic neurological sequelae of sensorimotor stroke. Motor hemiparesis, hemiplegia, and Rankin score of 3 or more were evaluated as poor prognosis. Patients were also evaluated for perioperative MI.

\section{Early and mid-term follow up}

All patients were evaluated on postoperative 7 th and 30th days, and again every 6 months by a neurologist, cardiologist, and surgeon. Average follow-up period was 52 months. (range: 12-65 months). Carotid Doppler USG was performed every 6 months.

\section{Statistical analysis}

Statistical analysis was conducted using IBM SPSS Statistics for Windows, Version 20.0. (IBM Corp., Armonk, NY, USA). Data are presented as mean and SD for continuous data and numbers (percentage) for categorical data.

\section{RESULTS}

Total of 412 carotid endarterectomies were performed on 370 patients under regional anesthesia in between 2009 and 2014. Demographic characteristics of the patients are presented in Table I; $29.4 \%(n=108)$ of the patients were female and $70.6 \%(n=262)$ were male. Mean age was 64 years (range: $42-86$ years). After preoperative physical examination and evaluation, $37.03 \%(n=137)$ of the patients were classified as symptomatic. Asymptomatic severe carotid artery stenosis ( $\geq 70 \%$ ) was diagnosed in $62.98 \%(n=233)$ of the patients. Carotid artery stenosis
Table I. Patient's characteristics

\begin{tabular}{|c|c|c|}
\hline & $\mathbf{n}$ & (\%) \\
\hline Age, Mean $\pm S D$ (min-max) & \multicolumn{2}{|c|}{$63.8 \pm 9.4(42-86)$} \\
\hline Female & 108 & 29.4 \\
\hline Male & 262 & 70.6 \\
\hline Body mass index $\left(\mathrm{kg} / \mathrm{m}^{2}\right)$, Mean $\pm \mathrm{SD}$ & \multicolumn{2}{|c|}{$27.6 \pm 4.6$} \\
\hline Hypertention & 326 & 88.1 \\
\hline Diabetes Mellitus & 87 & 23.51 \\
\hline Left ventricle dysfunction (<40\%) & 51 & 13.78 \\
\hline Renal dysfunction & 68 & 18.37 \\
\hline Chronic obstructive pulmonary disease & 126 & 34.05 \\
\hline Smoking & 136 & 36.75 \\
\hline Peripheric arterial disease & 79 & 21.35 \\
\hline ASA II & 137 & 37 \\
\hline ASA III & 233 & 63 \\
\hline Contralateral carotid disease & 42 & 11.35 \\
\hline \multicolumn{3}{|l|}{ Neurological status } \\
\hline Asymptomatic & 233 & 62.97 \\
\hline Symptomatic & 116 & 31.35 \\
\hline \multicolumn{3}{|l|}{ TIA } \\
\hline Stroke & 21 & 5.67 \\
\hline
\end{tabular}

DM: Diabetes mellitus; COPD: Chronic obstructive pulmonary disease; PAD: Periferic arterial disease; LVEF: Left ventricle ejection fraction; TIA: Transientischemic attack; Continous data are presented as mean \pm standard deviation, categorical data as number (\%).

Table 2. Perioperative and postoperative findings

\begin{tabular}{|c|c|c|}
\hline & $\mathbf{n}$ & $(\%)$ \\
\hline Carotid shunt & 41 & 9.95 \\
\hline Carotid clamping (time/min), Mean \pm SD & \multicolumn{2}{|c|}{$23.95 \pm 15.6$} \\
\hline \multicolumn{3}{|l|}{ Carotid closure technique } \\
\hline Direct suture & 70 & 16.99 \\
\hline Patchplasty & 330 & 80.34 \\
\hline Eversion & 12 & 2.91 \\
\hline \multicolumn{3}{|l|}{ Side of surgery } \\
\hline Left & 145 & 35.19 \\
\hline Right & 225 & 54.62 \\
\hline Bilateral & 42 & 10.19 \\
\hline Surgical care unit stay (hours), Mean \pm SD & \multicolumn{2}{|c|}{$2.84 \pm 1.20$} \\
\hline Hospital stay (days), Mean \pm SD & \multicolumn{2}{|c|}{$3.72 \pm 1.64$} \\
\hline
\end{tabular}

was confirmed by CT and angiography. Mean length of time of cross-clamp of the carotid artery was 23.95 ( \pm 15$)$ minutes. We performed bilateral carotid endarterectomy 
in $15.53 \%(n=64)$ of the patients; 42 underwent second separate operation for contralateral side. We used intraarterial shunt in $4 \mathrm{I}(9.95 \%)$ patients during operation. Primary suturing was used in 70 (16.9\%) patients for closure of arteriotomy. Patch plasty was required in 330 (80.34\%) patients. In 12 (2.91\%) patients, eversion technique was performed to repair arteriotomy. Follow-up parameters after surgery are provided in Table 2. Length of observation in intensive care unit following operation was 2.84 ( \pm 1.20$)$ hours, and total hospital stay was 3.72 ( \pm 1.64$)$ days. Restenosis was diagnosed in $7(1.69 \%)$ of the patients during follow-up period. Two patients underwent redo carotid endarterectomy, while stent implantation was performed for remaining 5 patients. Perioperative and early postoperative complications were classified as cardiac, pulmonary, or neurological. When compared to the literature

Table 3. Additional cardiac operations

\begin{tabular}{lcc}
\hline & $\mathbf{n}$ & $\mathbf{( \% )}$ \\
\hline CABG & 282 & 76.22 \\
CABG+AVR & 41 & 11.08 \\
CABG+ MVR+TVP & 5 & 1.36 \\
CABG +MVP & 10 & 2.70 \\
CABG+ Bentall+MVP+TVP & 16 & 4.32 \\
CABG+MVP+ascending aortic replacement & 4 & 1.08 \\
CABG+ABF & 7 & 1.89 \\
CABG+Aorto-Subclavian bypass & 5 & 1.35 \\
\hline CABG: Coronary artery bypass graft; AVR: Aortic valve replacement; MVR: \\
Mitral valve replacement; TVP: Tricuspid valvuloplasty; MVP: Mitral valvulop- \\
lasty; ABF: Aorto-bifemoral bypass. & \multicolumn{2}{c}{}
\end{tabular}

Table 4. Postoperative adverse outcomes in the first month, mortality and stroke

n

Postoperative morbidity

$\begin{array}{lcc}\text { Hematoma } & 13 & 3.15 \\ \text { Hoarseness } & 5 & 1.35 \\ \text { Cranial nerve palsy } & 3 & 0.72 \\ \text { Pulmonary complications } & 5 & 1.35 \\ \text { Neurological events } & 4 & 0.98 \\ \text { Cardiac events } & \\ \text { Otid restenosis (>50\% of diameter) } & 7 & 2.94 \\ \text { toperative mortality and stroke } & & 1.69 \\ \text { early term (30 days) } & & \\ \text { Mortality } & & \\ \text { Stroke } & 6 & 1.45 \\ \end{array}$

New onset cardiac event during postoperative period. regarding carotid endarterectomy with general anesthesia, rate of cardiac complications was similar (2.94\% and 3.7\%); however, fewer pulmonary complications occurred (I.35\% and $8.33 \%$ ). Number and frequency of patients who suffered early neurological events, such as stroke and transient ischemic attack (TIA) after operation, were similar to literature data as well $(0.98 \%$ and $0.72 \%)$ (Table 4$)$.

\section{DISCUSSION}

Surgical endarterectomy is standard and reliable approach in treatment of atherosclerotic stenosis of the carotid artery. Endovascular interventions (carotid angioplasty and stent implantation) have also become popular. Although various studies have confirmed advantages of these less invasive procedures, especially for elderly and high-risk patients, more detailed and long-term research is needed. ${ }^{[17]}$

North American Symptomatic Carotid Endarterectomy Trial (NASCET) and European Carotid Surgery Trial (ECST) are the most important and widely accepted studies regarding carotid surgery. Carotid endarterectomy is recommended in asymptomatic patients, if detected stenosis is greater than $85 \%$ and $70 \%$ according to NASCET and ECST, respectively. Experience of the medical center and coexisting risk factors are important in surgical decision. Benefits of surgery are closely related to grade of stenosis and perioperative complications. According to NASCET and ECST data, female sex; recent TIA, stroke, or retinal ischemia; and comorbid CAD are risk factors most likely to lead to perioperative complications.

Studies have demonstrated that carotid endarterectomy reduces mortality and cerebrovascular events in patients with carotid artery stenosis. However, severity of the stenosis is significant with respect to potential benefits of surgery. Results of NASCET indicated surgery reduced risk of mortality $12.5 \%$ in patient with severe (70-99\%) stenosis, but only $5 \%$ in patient with moderate (50-69\%) stenosis. According to ECST report, endarterectomy reduced mortality $12.9 \%$ in cases of severe $(70-99 \%)$ stenosis, and there was similar smaller decrease in risk of mortality in patients with moderate stenosis. Carotid endarterectomy is not useful in cases with less occluded arteries. ${ }^{[18,19]}$

Carotid endarterectomy in awake patient allows close follow-up of neurological functions and decision regarding necessity of intraarterial shunt during surgery. Use of intraluminal shunt and general anesthesia are routinely recommended in most studies, but unpleasant complications during placement of shunt into the internal carotid artery are well known. ${ }^{[20-24]}$

Anesthesia is the one of the most controversial issues of carotid endarterectomy. Detailed studies have reported cervical blockage has better results concerning perioperative stroke and cardiac events, such as arrhythmia and 
infarction. ${ }^{[21]}$ We also prefer regional anesthesia in appropriate patients. Certainly, evaluation of perioperative cerebral ischemia is very important for both. There are 2 methods to detect possible cerebral ischemia: direct method includes electroencephalogram (EEG), and followingup consciousness and cerebral potential responses, and indirect method, comprising transcranial Doppler, jugular vein oxygen pressure, and carotid artery stump pressure. In most studies, only I method was used in order to compare other parameters statistically. Intraluminal shunt use increased $20 \%$ to $25 \%$ in studies using EEG for cerebral monitoring, while $7 \%$ decrease was observed in patients who underwent carotid endarterectomy under regional anesthesia, which allows evaluation of consciousness and responses. ${ }^{[22,23]}$ Furthermore, EEG cannot always detect perioperative cerebrovascular events. Regional anesthesia and awake patient provide precise information and evaluation, facilitating decision about shunt according to the case. Most studies have found better results in terms of perioperative neurological complications with regional anesthesia compared with general anesthesia. ${ }^{[22,23]}$ Rate of use of intraluminal shunts in carotid endarterectomy was $10 \%$ to $15 \%$ in the literature. ${ }^{[24,25]}$ We used shunts in 2 patients $(9.5 \%)$ who had critical contralateral carotid artery stenosis. Melliere et al. compared general anesthesia group with regional anesthesia group in study involving 670 patients who underwent carotid endarterectomy. Rate of intraluminal shunt usage was $16.3 \%$ in general anesthesia group and $8.4 \%$ in regional anesthesia group. That study also demonstrated greater rate of perioperative neurological complications in general anesthesia group. ${ }^{[26]}$

Studies concerning restenosis after carotid surgery are few. Some have recommended patch plasty to prevent restenosis or occlusion. However, longer operative time, and risk of rupture or aneurysm have been reported as disadvantages of patch plasty in some studies. ${ }^{[27,28]}$ Myers et al. compared patch plasty and primary closure in terms of restenosis. No significant difference was found, but study did not include females or patients whose internal carotid artery diameter $\leq 5 \mathrm{~mm} \cdot{ }^{[29]}$ AbuRahma et al. demonstrated superiority of patch plasty in study of 399 patients. Restenosis rate was $34 \%$ in primary closure group, $2 \%$ in polytetrafluoroethylene graft group, and $9 \%$ in vein graft group. ${ }^{[30]}$ Present study results were patch plasty performed in 330 patients $(80.3 \%)$, primary closure in 70 patients ( $16.9 \%$ ), and eversion technique in 12 patients (2.9I\%). Facial vein was used as graft in eversion technique, and used polyester grafts were used for patch plasty procedures. Restenosis was detected in 7 patients; 4 in primary closure group, 2 in eversion group, and I in polyester graft group.

\section{Conclusion}

Awake carotid endarterectomy is safe and reliable method. Under regional anesthesia, patient consciousness can be optimally evaluated during operation, enabling precise determination of need for shunt and avoiding unnecessary use of shunt. This anesthesia technique reduces risk of stroke and cardiac complications in patients with heart disease.

Authorship contributions

Concept: K.Ö., Ü.A.; Design: K.Ö., Ü.A.; Data collection \&/or processing: K.Ö., B.E., O.A.; Analysis and/or interpretation: K.Ö., Ü.Z., B.O.; Literature search: K.Ö., B.E., Z.K.; Writing: K.Ö.; Critical review: B.E., M.E.

Conflict of interest

None declared.

\section{REFERENCES}

1. Naylor AR, Mehta Z, Rothwell PM, Bell PR. Carotid artery disease and stroke during coronary artery bypass: a critical review of the literature. Eur J Vasc Endovasc Surg 2002;23:283-94. [CrossRef]

2. Djaiani GN. Aortic arch atheroma: stroke reduction in cardiac surgical patients. Semin Cardiothorac Vasc Anesth 2006;10:143-57.

3. Faggioli GL, Curl GR, Ricotta JJ. The role of carotid screening before coronary artery bypass. J Vasc Surg 1990;12:724-31. [CrossRef]

4. Mas JL, Chatellier G, Beyssen B, Branchereau A, Moulin T, Becquemin JP, et al. Endarterectomy versus stenting in patients with symptomatic severe carotid stenosis. N Engl J Med 2006;355:1660-71.

5. Ringleb PA, Allenberg J, Brückmann H, Eckstein HH, Fraedrich G, Hartmann M, et al. 30 day results from the SPACE trial of stentprotected angioplasty versus carotid endarterectomy in symptomatic patients: a randomised non-inferiority trial. Lancet 2006;368:123947. [CrossRef]

6. Ederle J, Dobson J, Featherstone RL, Bonati LH, van der Worp HB, de Borst GJ, et al. Carotid artery stenting compared with endarterectomy in patients with symptomatic carotid stenosis (International Carotid Stenting Study): an interim analysis of a randomised controlled trial. Lancet 2010;375:985-97. [CrossRef]

7. Check W. Simultaneous coronary bypass and carotid endarterectomy advocated. JAMA 1978;240:725-6. [CrossRef]

8. Perler BA, Burdick JF, Williams GM. The safety of carotid endarterectomy at the time of coronary artery bypass surgery: analysis of results in a high-risk patient population. J Vasc Surg 1985;2:558-63.

9. Cambria RP, Ivarsson BL, Akins CW, Moncure AC, Brewster DC, Abbott WM. Simultaneous carotid and coronary disease: safety of the combined approach. J Vasc Surg 1989;9:56-64. [CrossRef]

10. Rizzo RJ, Whittemore AD, Couper GS, Donaldson MC, Aranki SF, Collins JJ, et al. Combined carotid and coronary revascularization: the preferred approach to the severe vasculopath. Ann Thorac Surg 1992;54:1099-109. [CrossRef]

11. Zacharias A, Schwann TA, Riordan CJ, Clark PM, Martinez B, Durham SJ, et al. Operative and 5-year outcomes of combined carotid and coronary revascularization: review of a large contemporary experience. Ann Thorac Surg 2002;73:491-8. [CrossRef]

12. Hertzer NR, Loop FD, Beven EG, O'Hara PJ, Krajewski LP. Surgical staging for simultaneous coronary and carotid disease: a study including prospective randomization. J Vasc Surg 1989;9:455-63. [CrossRef]

13. Salasidis GC, Latter DA, Steinmetz OK, Blair JF, Graham AM. Ca- 
rotid artery duplex scanning in preoperative assessment for coronary artery revascularization: the association between peripheral vascular disease, carotid artery stenosis, and stroke. J Vasc Surg 1995;21:15462. [CrossRef]

14. Ricotta JJ, Faggioli GL, Castilone A, Hassett JM. Risk factors for stroke after cardiac surgery: Buffalo Cardiac-Cerebral Study Group.J Vasc Surg 1995;21:359-64. [CrossRef]

15. Urbinati S, Di Pasquale G, Andreoli A, Lusa AM, Carini G, Grazi P, et al. Preoperative noninvasive coronary risk stratification in candidates for carotid endarterectomy. Stroke 1994;25:2022-7. [CrossRef]

16. Jones EL, Craver JM, Michalik RA, Murphy DA, Guyton RA, Bone DK, et al. Combined carotid and coronary operations: when are they necessary? J Thorac Cardiovasc Surg 1984;87:7-16.

17. Aburahma AF, Mousa AY, Stone PA. Shunting during carotid endarterectomy. J Vasc Surg 2011;54:1502-10. [CrossRef]

18. Randomised trial of endarterectomy for recently symptomatic carotid stenosis: final results of the MRC European Carotid Surgery Trial (ECST). Lancet 1998;351:1379-87. [CrossRef]

19. Barnett HJ, Taylor DW, Eliasziw M, Fox AJ, Ferguson GG, Haynes $\mathrm{RB}$, et al. Benefit of carotid endarterectomy in patients with symptomatic moderate or severe stenosis. North American Symptomatic Carotid Endarterectomy Trial Collaborators. N Engl J Med 1998;339:1415-25. [CrossRef]

20. Bonati LH, Fraedrich G. Age modifies the relative risk of stenting versus endarterectomy for symptomatic carotid stenosis--a pooled analysis of EVA-3S, SPACE and ICSS. Eur J Vasc Endovasc Surg 2011;41:153-8. [CrossRef]

21. Chou EL, Sgroi MD, Chen SL, Kuo IJ, Kabutey NK, Fujitani RM. Influence of gender and use of regional anesthesia on carotid endarterectomy outcomes. J Vasc Surg 2016;64:9-14. [CrossRef]

22. Pedrini L, Magnoni F, Sensi L, Pisano E, Ballestrazzi MS, Cirelli
MR, et al. Is Near-Infrared Spectroscopy a Reliable Method to Evaluate Clamping Ischemia during Carotid Surgery? Stroke Res Treat 2012;2012:156975.

23. Oz K, Aydın Ü, Kyaruzi M, Karaman Z, Göksel OS, Yeniterzi M, et al. Staged or Combined Approach for Carotid Endarterectomy in Pa-tients Undergoing Coronary Artery Bypass Grafting: A 5-YearLong Experience. Heart Surg Forum 2016;19:276-81. [CrossRef]

24. Pennekamp CW, Immink RV, den Ruijter HM, Kappelle LJ, Bots ML, Buhre WF, et al. Near infrared spectroscopy to indicate selective shunt useduring carotid endarterectomy. Eur J Vasc Endovasc Surg 2013;46:397-403. [CrossRef]

25. Aburahma AF, Stone PA, Hass SM, Dean LS, Habib J, Keiffer $\mathrm{T}$, et al. Prospective randomized trial of routine versus selective shunt-ing in carotid endarterectomy based on stump pressure. J Vasc Surg 2010;51:1133-8. [CrossRef]

26. Mellière D, Desgranges P, Becquemin JP, Selka D, Berrahal D, D'Audiffret A, et al. Surgery of the internal carotid: locoregional or general anesthesia?. Ann Chir 2000;125:530-8. [CrossRef]

27. Counsell C, Salinas R, Warlow C, Naylor R. Patch angioplasty versus primary closure for carotid endarterectomy. Cochrane Database Syst Rev 2000;2:CD000160.

28. Katras T, Baltazar U, Rush DS, Sutterfield WC, Harvill LM, Stanton PE. Durability of eversion carotid endarterectomy: comparison with primary closure and carotid patch angioplasty. J Vasc Surg 2001;34:453-8. [CrossRef]

29. Myers SI, Valentine RJ, Chervu A, Bowers BL, Clagett GP. Saphenous vein patch versus primary closure for carotid endarterectomy: long-term assessment of a randomized prospective study. J Vasc Surg 1994;19:15-22. [CrossRef]

30. AbuRahma AF, Stone P, Deem S, Dean LS, Keiffer T, Deem E. Proposed duplex velocity criteria for carotid restenosis following carotid endarterectomy with patch closure. J Vasc Surg 2009;50:286-91.

\section{Kardiyak Cerrahiye Giden Hastalarda Uyanık Karotid Endarterektomi: Altı Yıllık Deneyimimiz}

Amaç: Kardiyak cerrahiye giden ve anlamlı hemodinamik karotis darlı̆̆ı olan hastalarda en uygun cerrahi yaklaşım hala tartışmalıdır.

Gereç ve Yöntem: 2009-20I4 yılları arasında kardiyak cerrahi planlanan 370 hastaya (42 hastada iki taraflı karotis darlı̆ıı vardı) 4 I 2 karotid endarterektomi uygulandı. Tüm hastaların demografik verileri, risk faktörleri, peroperatif bulguları, 30. gün bulguları ve uzun dönem bulguları altı ayda bir kaydedildi. Veriler standart sapma ve ortalama olarak değerlendirildi.

Bulgular: Hastaların \%29'u (n=108) kadın ve \%70.6'sı (n=262) erkekti. Ortalama yaş 64 (dağııı, 42-86). Hastaların \%37.03'ü (n=|37) semptomatikti. \%70 ve üzeri kritik karotis darlığı olan hastaların \%62.98 $(n=233)$ semptomsuzdu. Ameliyat sonrası yoğun bakım takip süresi ortalama $2.84 \pm \mathrm{I} .20$ saat ve hastanede yatış süresi $3.72 \pm \mathrm{I} .64$ gündü. Takip sürecinde hastaların yedisinde $(\% \mathrm{I} .69)$ yeniden darlık oluşmuştu. Erken dönemdeki kardiyak komplikasyon ve inme oranları \%2.94 ve \%0.72 idi.

Sonuç: Kardiyak cerrahiye gidecek karotis endarterektomi hastalarında, kombine ya da aşamalı yapılmasının birbirlerine bazı üstünlükleri bulunmaktadır. Aşamalı yaklaşım intraluminal şant kullanımını azalttığından nörolojik riskleri azaltmaktadır. Uyanık karotid endarterektomi güvenli bir yöntemdir. Hastanın bilinç durumu tam olarak değerlendirilebildiğinden, şant ihtiyacına tam olarak karar verilebilmekde ve gereksiz şant kullanımı ve riskleri azalmaktadır.

Anahtar Sözcükler: Bölgesel anestezi; kardiyak cerrahi; karotid endarterektomi. 